\section{Innovative human resource management: measurement, determinants and outcomes}

Innovative human resource management

\author{
Ferry Koster
}

Department of Public Administration and Sociology, Erasmus Universiteit Rotterdam, Rotterdam, The Netherlands, and

Luc Benda

CPB Netherlands Bureau for Economic Policy Analysis, Erasmus Universiteit Rotterdam, Rotterdam, The Netherlands

\begin{abstract}
Purpose - External factors such as global competition and new technologies, require organizations to be innovative. Such organizational innovations also ask for innovative human resource management (HRM). However, in the current literature, it is not completely clear what innovative HRM means, as it is conceptualized in different ways. This study aims to provide clarity about innovative HRM by suggesting a new measurement scale; formulating hypotheses about some core determinants of innovative HRM; and investigating how innovative HRM relates to organizational innovation.

Design/methodology/approach - Using a sample of 719 Dutch organizations it was possible to investigate the properties of the inventory and examining several determinants of innovative HRM and how it relates to organizational innovation.

Findings - The innovative HRM scale is internally consistent and differs from other HRM indicators. It is explained by external developments, organizational size and stability of the organization. Finally, innovative HRM is a predictor of organizational innovation.

Originality/value - The measure that was developed in this paper is new to the literature. Innovative HRM has not been measured in a similar way to date. Besides that, the innovative HRM Survey is a novel data set.
\end{abstract}

Keywords Innovation performance, Measurement, External developments, Innovative HRM

Paper type Research paper

\section{Introduction}

The innovativeness of organizations is crucial in today's competitive environment (Hult et al., 2004; Damanpour et al., 2009; Tidd and Bessant, 2018). Organizational innovation, however, is a broad term, which refers to different facets (Armbruster et al., 2008; Crossan and Apaydin, 2010). These facets include the adoption of new ideas or behaviors, which can be a system, policy, program, device, process, product or service (Damanpour et al., 1989;

(C) Ferry Koster and Luc Benda. Published by Emerald Publishing Limited. This article is published under the Creative Commons Attribution (CC BY 4.0) licence. Anyone may reproduce, distribute, translate and create derivative works of this article (for both commercial and non-commercial purposes), subject to full attribution to the original publication and authors. The full terms of this licence may be seen at: http:// creativecommons.org/licences/by/4.0/legalcode

The authors thank the Dutch Research Council (NWO) for financial support (NWO Top Project "Sustaining Employability" 407-13-021).
Received 14 March 2020 Revised 21 April 2020 Accepted 1 May 2020 
Damanpour, 1992). In other words, anything that is new to the organization can be termed an innovation. To get a grip on the concept of organizational innovation, researchers have distinguished different dimensions. One of these distinctions differentiates between product and service innovations on the one hand and process and organizational innovations on the other (Armbruster et al., 2008). The first kind of innovation focuses on the outcomes that organizations produce and is studied most often (Pouwels and Koster, 2017). This approach to innovation reflects the view that innovation refers to the creation of novel outputs, which are not yet available on the market or which are new to the organization. The second approach to organizational innovation focuses on organizational processes, referring to the way in which organizations are designed and processes are managed (Maine et al., 2012). As Crossan and Apaydin (2010) put it: "it [innovation] is both a process and an outcome" (p. 1155). While there is discussion whether innovations refer to changes in output and processes in general or that it needs to involve improvements of these outputs, it may be assumed that innovations are at least aimed at adding value to the organization. In that light, the question whether an innovation is successful (in terms of financial performance or higher quality) is an additional question that is often not answered. In the present study, this "newness" aspect of innovations in the domain of human resource management (HRM) is taken as a point of departure. Furthermore, it explicitly links innovation in HRM to the innovativeness of organizations.

Innovative HRM can be placed in of both strands of the innovation literature; it can focus on the question of what innovative human resource (HR) policies and practices organizations apply as a response to external forces, as well as on the question, which HR practices and policies enhance the innovativeness of organizations (Agarwala, 2003; Laursen and Foss, 2003; Sels et al., 2006; Wolfe et al., 2006; Shipton et al., 2006; Chen and Huang, 2009; Oladapo and Onyeaso, 2013; Shipton et al., 2017; Koster, 2019). The first conceptualization of innovative HRM emphasizes the renewal of organizational processes by changing HRM policies and practices and the second focuses on its contribution to new products and services. Hence, innovative HRM is studied as the dependent and the independent variable. Given that these two meanings can lead to confusion amongst those discussing innovative HRM, both in academia and in practice, it is necessary to be precise about, which conceptualization is followed.

The present article aims to contribute to clarifying the concept of innovative HRM. First, a measure of innovative HRM is developed in line with measures that are used in studies of organizational innovation. To date, such a measure is not available and, hence, the focus is on the question of how innovative HRM can be measured. Second, the question is which organizations adopt innovative HR practices and policies. Therefore, several hypotheses are formulated that link characteristics of organizations to innovative HRM. Finally, the link between innovative HRM and organizational innovation is investigated. These three questions are answered using a recently conducted survey among 719 private organizations in The Netherlands.

\section{Two approaches to innovative human resource management}

Contingency theory, along with related theoretical approaches such as the resource-based view, dynamic capabilities theory and human capital theory, is one of the main theoretical underpinnings of approaches to innovative HRM focusing on how organizations adapt their HR practices and policies to internal and external circumstances (Subramony, 2006; Som, 2007, 2012; Koster and Wittek, 2016). The major theoretical argument is that organizations that are internally and externally aligned perform better than those lacking these two kinds of fit. In the field of HRM, this theoretical view is widely adopted. With regard to the fit concept, two theoretical approaches are distinguished, namely, a "best practice" and a "best fit" view. 
An example of the best practices conception of innovative HRM is provided by the highperformance work practices (HPWPs) literature (Appelbaum et al., 2000; Murphy and Southey, 2003), which emphasizes the importance of specific practices aimed at the motivation and engagement of employees. Examples of these practices are the application of worker autonomy and skill enhancement. Here the internal fit refers to the internal cohesion of the practices that are applied (in the sense that they provide a clear and consistent message to employees) and the external fit is achieved as organizational members have the ability to adjust their work to external demands (Huselid, 1995; Koster, 2011). In other words, research investigating HPWPs of organizations focus on a set of predefined HRM policies and practices, which are regarded superior and organizations applying these practices are believed to perform better than those who do not apply the practices. Hence, the focus is on the content of the practices. Several studies show that HPWPs are indeed related to organizational innovation (Walsworth and Verma, 2007; Jimenez-Jimenez and Sanz-Valle, 2008; Fu et al., 2015; Rasheed et al., 2017). However, an important point of criticism to this approach focuses on the universal impact of these practices on organizational innovation. Instead, it is argued that the need for applying these practices differs across organizations. In addition, it is possible that these best practices are not good for all organizations. The need for applying them depends on characteristics of organizations and the context in which they operate (Kaufman and Miller, 2011).

What can be termed the "best fit" approach does not focus on the content of the practices, but on the adaptability of organizations regarding the design and implementation of these practices. In that sense, this view of innovative HRM closely relates to how innovation is approached in the innovation literature. Innovation studies are to a large extent based on the question whether organizations generate new products and services, adopt new technologies and find new markets for their goods and services (Johne, 1999; Hong et al., 2012) and do not focus on what products and services are introduced, which kind of technologies are adopted and which markets are explored. Instead, it focuses on whether organizations have undertaken any change in these areas and then try to explain why this occurred. Several surveys have adopted this approach to innovation and ask respondents whether their organization introduced new products/goods and services, operate on new markets, introduced new management techniques and so forth. Examples are the Community Innovation Survey, the European Company Survey, the Business Environment and Enterprise Performance Surveys and the World Bank Enterprise Survey. Data from these surveys are analyzed in several empirical papers investigating organizational innovation (Evangelista and Vezzani, 2011; Nguyen and Jaramillo, 2014; Fritsch and Görg, 2015; Pouwels and Koster, 2017; Ramadani et al., 2017; Goel and Nelson, 2018; Mateut, 2018; Morris, 2018; Wellalage and Fernandez, 2019).

While measures of the "best practice" approach to innovative HRM are widely available, the same does not hold for the "best fit" approach. The measures that have been developed in the literature on organizational innovation pave the way for developing such a measure.

\section{Measuring innovative human resource management}

From the previous sections, the following conclusions can be drawn. First, that there is a tendency among innovation scholars to measure innovation by asking informants of organizations whether new products or services were developed, new markets were explored or new organizational processes were introduced. In addition, secondly, that in the field of HRM the focus is on "best practice" instead of "best fit" measures of innovative HRM. It is possible to connect these two streams of research by applying the notion of innovation researchers to the management of HRs in organizations. Just like the general 
measures of innovation found in other surveys - discussed in the previous section of this article - the scale measuring innovative HRM developed here focuses on general functions of HRM. Similar to these general measures of innovation that ask whether organizations have developed new products and services instead of asking about the content of the innovation, the innovative HRM scale asks whether organizations have adopted new policies and practices within a number of HR functions instead of asking, which work practices they use. The innovative HRM scale focuses on the following four general HR functions, covering the main practices that organizations require to manage their employees.

\section{Hiring personnel}

The hiring function of organizations is vital to their functioning as it aims at the recruitment and staffing of valuable HRs (Gerxhani and Koster, 2015). As such, it is one of the main means of acquiring human capital needed for organizations to perform well.

\section{Outflow of personnel}

The second set of HR practices focuses on the means to adapt the workforce to changing demands. Such practices are needed if jobs are changing or (the skills of) workers become obsolete. Having these practices in place provides that organizations possess the flexibility required in competitive markets (Doherty, 1998).

\section{Internal mobility of personnel}

Organizational flexibility is also established through practices aimed at the internal mobility of employees. By having means to internally adjust the workforce, organizations can respond to changing demands. Furthermore, practices aimed at internal mobility reflect the way organizations structure the career opportunities for employees, which enables them to optimize their human capital (Tzafrir, 2005).

\section{Workforce composition}

Finally, the performance of organizations depends on the extent to which they are able to manage the composition of the workforce. This function relates to several aspects, such as managing the required diversity of the workforce and their ability to manage the stock of human capital through training and education ( $\mathrm{Ng}$ and Dastmalchian, 2011).

\section{Determinants and outcomes of innovative human resource management}

As already mentioned, the contingency theory may explain why organizations engage in innovative HRM. Based on this overarching theoretical framework, a number of specific hypotheses are formulated. These hypotheses relate to the need to innovate, organizational characteristics that enable organizations to adjust their HR policies and practices and whether establishing a better fit by applying innovative HR practices in the organization relates to organizational innovation.

\section{Need to apply innovative human resource management}

With its focus on external fit, contingency theory argues that organizations need to adapt to external circumstances. This means that whether or not organizations innovate HR functions depends on what happens in their external environment, which is also shown in studies that find that organizational innovations are driven by need. Hence, if organizations face challenges and changes, they may be more likely to innovate their HR functions 
(Subramony, 2006; Wu et al., 2014) Therefore, it is expected that organizations engage more in innovative HRM if they anticipate external developments:

H1. There is a positive relation between innovative HRM and external developments.
Innovative human

resource management

\section{Enablers of innovative human resource management}

Next to the need to innovate the HRM function, there are several characteristics of organizations that enable them to innovate. These enablers are also closely relate to the ability of organizations to generate external and internal fit.

First, the size of the organization may matter. Previous studies have shown that there is a positive relation between organization size and the application of HR practices, even though a small organization may be innovative as well (Cassell et al., 2002; Zheng et al., 2009; Wu et al., 2014). Furthermore, this link is also found for innovativeness in general (Pouwels and Koster, 2017). An important theoretical reason for this is that larger organizations possess more resources, enabling them to introduce new ways of working:

H2. There is a positive relation between innovative HRM and organizational size.

Secondly, the internal and external fit may benefit from the stability of the organization; if the organization is more stable, it may have more time to adapt to changes and develop learning routines (March, 1991) for organizational change (Feldman, 2000) that contribute to organizational innovation (Koster and Lambooij, 2018). If there is a longer-term relation between employees and the organization, the tendency to mutually invest in the employment relationship may be greater, in turn enabling organizations to achieve internal and external fit (Shaw et al., 2009). This leads to the expectation that the more permanent employees are employed in the organization, the more likely it is that the innovation of HRM takes place:

H3. There is a positive relation between innovative HRM and the number of permanent employees in the organization.

Finally, the external and internal fit may depend on the skill level of the organization. Based on human capital arguments, it can be argued that organizations possessing a larger stock of human capital also have a higher stake in developing their HRs (Lepak and Snell, 1999). Hence, it is expected that the higher educated the workforce, the more likely it is that organizations engage in innovative HRM:

H4. There is a positive relation between innovative HRM and the skill level of employees in the organization.

The contribution of innovative human resource management to organizational innovation Besides the well-established link between HRM practices and policies and innovation, HRM innovation matters for organizational innovation. From the "best fit" approach to innovative HRM, it can be derived that organizations that are able to adjust their HRs to generate external and internal fit will also be more capable of producing novel outcomes (Crossan and Apaydin, 2010):

H5. There is a positive relation between organizational innovation and innovative HRM. 


\section{Procedure, data and measurement}

Development of the innovative human resource management scale

The scale measuring innovative HRs practices is developed and analyzed in a number of steps in line with procedures suggested by, for example, Hinkin (1998) and Carpenter (2018). The main steps to be taken involve as follows:

- the generation of the items measuring the theoretical construct;

- questionnaire administration and issues regarding sample size;

- exploratory factor analysis (and item reduction);

- confirmatory factor analysis (CFA); and

- analyzing how the items relate to similar items.

The development of the individual items took place in a number of steps. First, there were discussions with a panel of experts, consisting of both innovation and HRM researchers and experts from the field (e.g. consultants of organizations and trade organizations). This panel aimed at developing items that satisfied two criteria, namely:

(1) the items needed to be similarly constructed as existing measures used in innovation studies; and

(2) the items needed to capture the HRM of organizations.

Reviewing existing measures of organizational innovation and taking the wording of prior surveys as a model for the newly developed items met this first criterion. The discussion of the second criterion leads to the insight that a focus on functional fields of HRM could be linked to the innovation measures. Secondly, the suggested items were discussed with a scientific board overlooking the progress of this research. This board consisted of researchers and consultants that provided criticisms and shared their ideas with the researchers. After the items passed these two panels, the items were sent to the organization collecting the data (Kantar; see below for more information). Two researchers of Kantar with extensive experience in collecting survey data among organizations reviewed the items (along with the whole questionnaire). Finally, the items were pre-tested among a small selection of organizations. Respondents were asked to provide comments about the measures. The resulting measures are provided under the heading "measures" below.

The data for this study are available through the innovative HRM Survey (Koster et al, 2017). This data were collected among a random sample of Dutch firms. The questionnaire was developed to measure several characteristics of organizations, related to their innovativeness. Among these measures are the innovative HRM scale introduced in this study, the composition of the workforce and a number of core characteristics of the organizations. Kantar Public collected the data using their panel with private organizations (NIPObase Business). The panel consists of 15,000 representatives from Dutch firms. From this panel, a random selection of 3,000 organizations was drawn. The response rate was $25 \%$ (752 responding organizations). Some variables are not available for all organizations. For 33 organizations not all variables included in this study were missing, meaning that the analyzes could be conducted on a sample of 719 organizations. These organizations operate in different economic sectors and differ in size. Altogether, these organizations provide a cross-section of the Dutch economy.

\section{Measures}

Innovative human resource management. To assess the extent to which organizations engage in innovative HRM, a new measurement scale was developed. Based on the 
conceptualization that was outlined in the theory section, this measure is based on four questions about whether the organization renewed their HR function. The exact wording is: "has your organization innovated in the area of [...]." followed by four statements about the HR functions, namely, "hiring personnel," "outflow of personnel," "internal mobility of personnel" and "workforce composition." Respondents were asked to indicate how much this applied to their organization on a five-point scale (running from $1=$ does not apply at all to 5 = does apply completely).

To allow for a comparison of innovative HRM with other aspects of the HRM, questions

Innovative human resource management

293 were asked about HRM collaboration and organizational learning practices. HRM collaboration was measured by asking respondents to rate on a five-point scale whether the organization cooperates with other organizations with regard to "[ . . . hiring and selection," "[...] training," "[...] internal mobility," "[...] reward structure" and "[...] outflow of personnel." The variable organizational learning practices were measured by asking whether "the organization has a yearly budget for the development of personnel;" "the organization uses training;" "employees are trained on the job;" "whether a training period is required for new workers;" and "skill needs are regularly assessed." The items are also measured on a five-point scale.

The three measures provide the input for Steps 3-5 in the construction of the scale, namely, exploratory factor analysis, CFA and analyzing whether the items of the scale deviate from similar constructs. Step 5 is merged with the exploratory factor analysis and the confirmatory analysis as all items are analyzed to investigate whether they actually measure three distinct dimensions of HRM. In the construction of the innovative HRM scale, two analytical techniques were used, namely, principal component analysis (PCA) and CFA. The PCA was conducted with the psych package (Revelle, 2018) in R and the CFA was conducted with the lavaan package (Rosseel, 2012) in R. First, a PCA was performed on the four Likert-items that measure innovative HRM. To verify that the developed innovative HRM scale is not a proxy for the presence of HRM in general or specific HRM policies and practices, another PCA was performed. In total, 14 items were included that measure organizational practices related to learning and collaboration in HRM between organizations. The analysis was performed in two steps. First, the analysis showed that these 14 items consist of three components with eigenvalues greater than one. Then another PCA was performed with oblimin rotation to improve the interpretability of the results (Table 1). Additionally, a CFA was conducted. The CFA was performed with the additional items that measure learning activities and collaboration in HRM. The scales were calculated based on the average score on the relevant items (Table 2).

The exploratory factor analysis and the CFA lead to the same conclusions. On the one hand, it holds that the individual items load on the dimension to which it was assigned beforehand. Furthermore, the resulting scales are considered internally consistent with reliability scores of 0.93 (innovative HRM), 0.93 (HRM collaboration) and 0.80 (organizational learning practices). Besides, as Tables 1 and 2 show, the individual items load on their respective dimension and not on one of the others. This finding means that the three scales can be considered independent measures of the HRM policies and practices of organizations. To conduct further analyzes, three scales are constructed. For each of the scales, the scores of the individual items are added up and divided by the number of items of the scale.

\section{Independent variables}

The independent variables of this study are measured as follows. The variable developments expected are a composition of several items asking respondents to indicate whether they expect that the organization will experience the following issues in the near future: employee 
Renewal of ...

... hiring personnel

0.920

. . . internal mobility of personnel

0.916

... outflow of personnel

0.897

... workforce composition

0.914

Collaboration with other organizations in [. . .]

... hiring

0.879

... training

0.851

... internal mobility

0.917

... reward structure

0.903

... outflow of personnel

0.848

Organizational learning practices

The yearly budget for the development of personnel

Uses training

On-the-job training

New personnel needs training time

0.606

Regular assessments of skill needs

0.633

Eigenvalue

3.326

Proportion of variance

0.826

Table 1.

0.238

2.674

Principal component analysis

Cronbach's alpha

Source: Innovative HRM Survey, $N=719$ and rotation: oblimin

Innovation in ...

... hiring personnel

... internal mobility of personnel

... outflow of personnel

... workforce composition

0.93
3.927

0.280

0.93

Collaboration with other organizations in [...]

$[\ldots]$ hiring
$[\ldots]$ training
$[\ldots]$ internal mobility
$[\ldots]$ reward structure
$[\ldots]$ outflow of personnel

Organizational learning practices

The yearly budget for the development of personnel

Uses training

On-the-job training

Training time needed for new workers

Regular assessments of skill needs

\section{Covariances}

Innovation $\sim$ collaboration

Innovation $\sim$ organizational learning practices

Collaboration $\sim$ organizational learning practices

CFI

Table 2.

RMSEA

SRMR

$\begin{array}{lc}\begin{array}{l}\text { Estimate } \\ 1.000\end{array} & \text { s.e. } \\ 0.837 * * * & \\ 0.790^{* * *} & 0.024 \\ 1.001 * * * & 0.025 \\ & 0.028 \\ 1.000 & \\ 1.066^{* * * *} & \\ 0.990^{* * *} & 0.035 \\ 0.972^{* * * *} & 0.029 \\ 0.864 * * * & 0.029 \\ & 0.027\end{array}$

1.000

$1.031^{* * * *} \quad 0.058$

$0.627 * * * * 0.058$

$1.097 * * * \quad 0.065$

1.157 **** $\quad 0.057$

$0.462^{* * * *} \quad 0.039$

$0.457 * * * \quad 0.041$

$0.386^{* * * *} \quad 0.037$

0.959

0.075

0.047

CFA of HRM

Source: Innovative HRM Survey, $N=719$, ${ }^{* * *} p<0.001$ 
ageing, flexibilization, internationalization, robotization and digitalization. While these five issues reflect different trends in organizations, factor analysis and reliability analysis show that they reflect an underlying dimension (Cronbach's alpha is 0.75). This means that organizations facing one issue are also likely to face other issues. Because these items are strongly-related, they are added up and divided by 5 to measure the overall variable: developments expected. Organization size is measured by asking respondents to indicate the number of employees that the organization has. The sector was measured by asking respondents in what economic sector the organization operated. The variable permanent employees were measured by asking respondents to indicate to what extent the organization consists of employees with a permanent contract (measured on a five-point scale). The variable highly educated was measured with a five-point scale indicating to what extent the organization consists of highly educated employees.

\section{Outcome variable}

Organizational innovation. To get a broad measure of innovation performance (one that goes beyond measures of product and service innovation) it is asked whether the organization:

- Developed goods or services that are new for his organization (but already available on the market).

- Introduced goods or services that were not on the market yet.

- Strongly improved existing goods and services.

- Introduced new ways of marketing goods and services.

- Introduced new organizational processes.

These items also form a reliable scale (Cronbach's alpha $=0.86)$. To be sure that the items measuring innovative HRM and the ones measuring organizational innovation do not belong to the same dimension (measuring innovation in general), a PCA was conducted. The analysis shows that the two dimensions are distinct (not reported here, but available upon request).

\section{Analyzes}

The hypotheses are tested using ordinary least squares (OLS) regression analysis to examine the factors proposed in the theory section. Several models are investigated. In the first model (Model 1), innovative HRM is the dependent variable. The independent variables are added to test $H 1-H 4$. The hypothesis $H 5$ states that innovative HRM is related to organizational innovation and is investigated in the second model (Model 2). Here organizational innovation is the dependent variable and innovative HRM is added as one of the independent variables.

\section{Results}

Descriptive statistics

Table 3 provides insight into the variables measured in the innovative HRM Survey that were included in this study. The descriptive results confirm that the data are a cross-section of the Dutch economy (the majority of organizations is small or medium enterprise) and the organizations reflect the size of the different economic sectors.
Innovative human

resource management

295 


\begin{tabular}{|c|c|c|c|c|c|}
\hline \multirow{2}{*}{$\begin{array}{l}\text { IJIS } \\
12,3\end{array}$} & & Min/Max & Mean & $\mathrm{SD}$ & $(\%)$ \\
\hline & $\begin{array}{l}\text { Innovative HRM } \\
\text { Organization size }\end{array}$ & $\begin{array}{l}1 / 5 \\
1 / 5\end{array}$ & $\begin{array}{l}1.80 \\
1.17\end{array}$ & $\begin{array}{l}0.91 \\
0.58\end{array}$ & \\
\hline \multirow[t]{2}{*}{296} & $\begin{array}{l}\text { Organization size (categories) } \\
1-9 \\
10-49 \\
50-99 \\
100-249 \\
250 \text { or more }\end{array}$ & $\begin{array}{l}0 / 1 \\
0 / 1 \\
0 / 1 \\
0 / 1 \\
0 / 1\end{array}$ & & & $\begin{array}{r}89.50 \\
6.50 \\
1.70 \\
0.90 \\
0.90\end{array}$ \\
\hline & $\begin{array}{l}\text { Sector } \\
\text { Industry and production } \\
\text { Construction } \\
\text { Retail - food } \\
\text { Retail - nonfood } \\
\text { Wholesale } \\
\text { Cars and repair } \\
\text { Catering } \\
\text { Transport and communication } \\
\text { Business services } \\
\text { Other services } \\
\text { Information technology } \\
\text { Financial institutions } \\
\text { Permanent employees } \\
\text { Highly educated } \\
\text { Developments expected } \\
\text { HRM collaboration } \\
\text { Organizational learning practices }\end{array}$ & $\begin{array}{l}0 / 1 \\
0 / 1 \\
0 / 1 \\
0 / 1 \\
0 / 1 \\
0 / 1 \\
0 / 1 \\
0 / 1 \\
0 / 1 \\
0 / 1 \\
0 / 1 \\
0 / 1 \\
1 / 5 \\
1 / 5 \\
1 / 5 \\
1 / 5 \\
1 / 5\end{array}$ & $\begin{array}{l}2.99 \\
2.94 \\
2.45 \\
1.80 \\
2.73\end{array}$ & $\begin{array}{l}1.69 \\
1.58 \\
0.89 \\
0.89 \\
0.96\end{array}$ & $\begin{array}{r}4.70 \\
6.60 \\
3.10 \\
13.20 \\
7.40 \\
1.90 \\
3.90 \\
3.20 \\
35.20 \\
10.20 \\
8.50 \\
2.10\end{array}$ \\
\hline Descriptive statistics & Source: Innovative HRM Survey & & & & \\
\hline
\end{tabular}

Regression analysis

The hypotheses of the determinants of innovative HRM are tested in Model 1. Together, the independent variables explain $37 \%$ of the variation in innovative HRM. The innovativeness of HRM is higher in organizations that expect to face a number of changes in the external environment ("developments expected"), in larger organizations and in more stable organizations ("permanent employees"). The skill level of the employees in the organization is not related to innovative HRM. Together these findings corroborate $H 1$ through H3. H4 is not supported. Overall, this means that the innovativeness of HRM depends on several features of organizations; if they need to innovate is higher, if they have more resources and if they are more stable, they are more likely to be innovative regarding their HR policies and practices. Furthermore, the analyzes show that innovative HRM varies across the sectors in which the organizations operate. In particular, organizations in the cars and repair and the catering sector report higher levels of innovative HRM. While this variable was included to account for variation between the sectors and, hence, no expectations were formulated that are tested, there may be some ad hoc explanations for these differences. One of these interpretations is that part of the differences can be understood in terms of these organizations catching up in terms of the renewal of their HR policies and practices. This would be in line with the "best fit" interpretation of 
innovative HRM; in sectors that may be regarded as a bit more traditional there is more to gain in terms of renewal and creation of fit than in sectors that have already innovated their HR policies and practices.

In Model 2, organizational innovation is the dependent variable. The independent variables explain $46 \%$ of the variation in organizational innovation. To test $H 5$, the variable innovative HRM is added to this regression. Controlling for other characteristics of the organizations, it turns out that innovative HRM is a predictor of organizational innovation $(\beta=0.28 ; p<0.001)$. Hence, the outcomes support H5. This means that the more an organization renews its HR functions, the higher the organizational innovation it reports. This is in line with the expectation that to be innovative, organizations may need to make adjustments in the way in which they manage their personnel. What is further evident from the model explaining organizational innovation, is that the other two HRM-related practices, namely, collaborating with other organizations and the development of organizational learning practices, also contribute to it. As all three indicators of HRM policies and practices are statistically significant, it can be concluded that they contribute to organizational innovation independent of each other. The interpretation of these results mainly reflects the theoretical notions that knowledge management and learning are relevant preconditions of organizational innovation. What is more, the sources of information and learning can be internal (through the development of organizational learning practices) or external (by collaborating with other organizations) (Table 4).

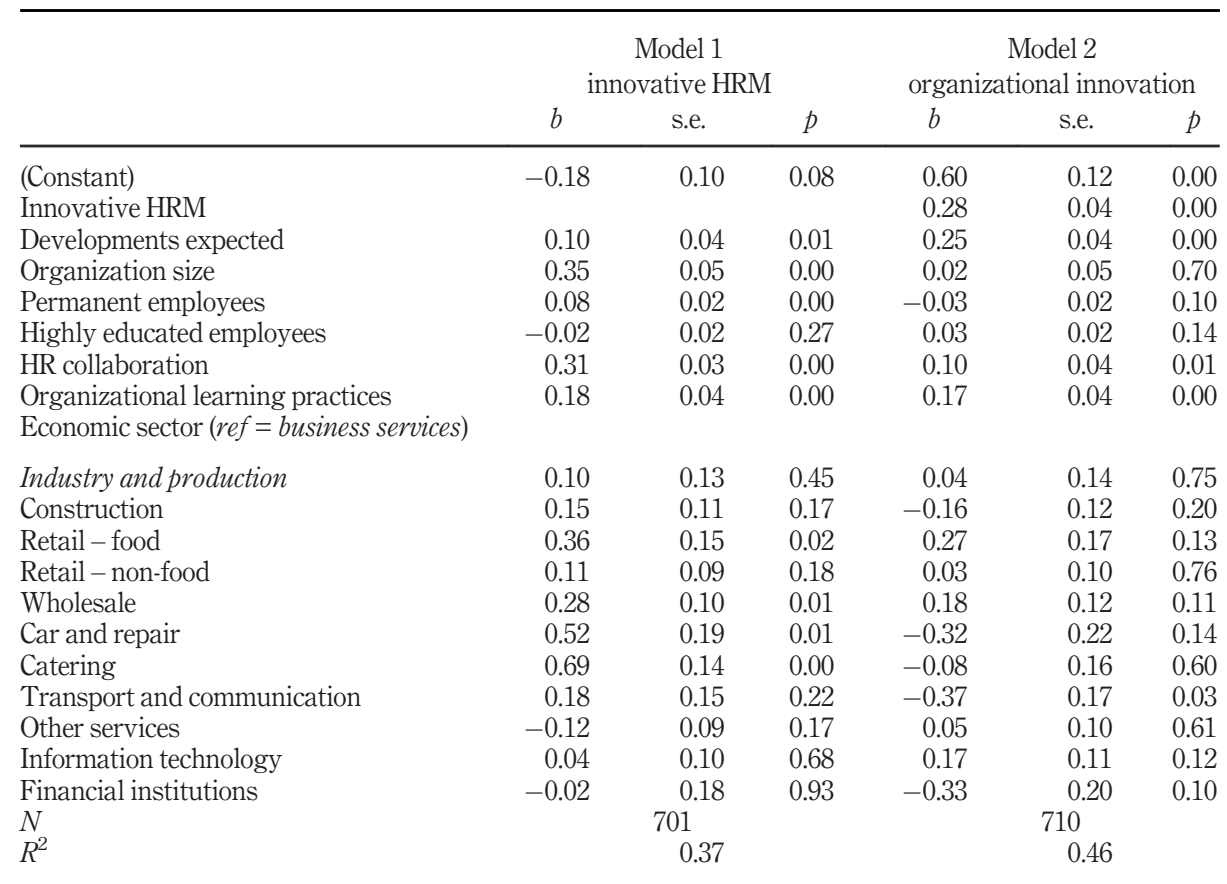

Source: Innovative HRM Survey
Innovative human

resource management

297
Table 4.

OLS regression of innovative HRM and organizational innovation 
IJIS

12,3

298

\section{Discussion and conclusion}

This study proposed and empirically assessed a measure of innovative HRM by applying measures of organizational innovation to HRM. One of the aims of the present study was to provide more insight into innovative HRM in the sense of creating the best fit, next to the already extensive literature on best practices.

The study leads to the following conclusions. First, innovative HRM can be meaningfully measured. It is distinct from other aspects measuring HRM and the more general organizational innovation. Hence, it adds a dimension to HRM that was not yet available in the literature in the form proposed in this article. This provides researchers with a tool to further examine how organizations try to create internal and external fit. Secondly, the theoretical notion of fit - both internal and external - is central to contingency theory. A number of theoretical predictions derived from this general theoretical framework are supported by the empirical analysis. Organizations strive for the best fit of their HRM under conditions hypothesized by contingency theory, in particular changes in the environment of the organization and characteristics that enable organizations to achieve a better fit. Thirdly, innovative HRM is one of the main predictors of organizational innovation in the present study. This provides further evidence that the best-fit approach to innovation of HRM matters for the functioning of organizations. Besides having best practices, have a good fit - as contingency theory predicts - makes a different with regard to organizational innovation.

The outcomes of this study lead to a number of questions that need to be addressed in future research. First, while the measure of innovative HRM focused on four core HR domains (attracting human capital, the outflow of human capital, the development of human capital and the composition of human capital), this measure can be extended in a number of ways, namely:

- adding other HR domains;

- adding detail about the policies and practices; and

- adding other kinds of HR innovation.

To begin with, this means extending the list with questions about other HR domains. In other words, while the measure as proposed here works out well (in terms of internal consistency and explaining organizational innovation), it cannot be ruled out that other HR domains should also have been included in the measures. Next to that, it would be possible to further extent the innovative HRM measure by asking about the introduction of specific policies and practices. Doing that enables researchers to go into more depth. However, a potential downside of that could be that comparisons across organizations and sectors become more difficult. In addition, the third point could be added by focusing, for example, on the use of eHRM. For now, these were not included, but these aspects can be added in a new data collection and then tested. More generally, collecting new data is required to assess the usefulness of the measure that is proposed here. It can be argued that the data were collected in a specific context (the Dutch economy), which has characteristics affecting the results. Hence, collecting data among organizations in other countries is needed to investigate whether it applies in other contexts. Finally, a theoretical issue, which was not addressed in the present study needs further attention, namely, concerning how "best practice" and "best fit" approaches relate to each other. The present study suggests that these two approaches are not mutually exclusive. Instead, they may be combined; while the "best practice" approach helps to select, which HRM policies and practices matter for organizational innovation the "best fit" approach focuses on the underlying process. If that 
is the case, these two approaches are basically complementary to each other and further integration would lead to a theoretically richer model in which it can be answered, which practices matter and why they matter. For the moment, it is not possible to conclude whether this is indeed the case.

The present study generates some insights that can be of use to (HR) managers of organizations. First, given that the innovations of the HR functions are interrelated, the study suggests that it makes sense to introduce different HR innovations similarly. Organizations doing that can achieve an internal fit between the practices. Innovation only one of the HR functions may actually undermine the existing fit. Then, the results show that innovative HRM is strongly related to the expectation that the organization faces issues in the near future. This may underscore that organizations that are likely to experience these issues try to be prepared for the future. For practitioners, this implies that they should consider if their organization has to deal with similar issues (in other words: enhancing their capability to look forward) and, in addition to that, if innovative HRM is required to deal with the issues.

\section{References}

Agarwala, T. (2003), "Innovative human resource practices and organizational commitment: an empirical investigation", The International Journal of Human Resource Management, Vol. 14 No. 2, pp. 175-197.

Appelbaum, E., Bailey, T., Berg, P. and Kalleberg, A.L. (2000), Manufacturing Advantage: Why HighPerformance Work Systems Pay off, Cornell University Press, Ithaca.

Armbruster, H., Bikfalvi, A., Kinkel, S. and Lay, G. (2008), "Organizational innovation: the challenge of measuring non-technical innovation in large-scale surveys", Technovation, Vol. 28 No. 10, pp. 644-657.

Carpenter, S. (2018), "Ten steps in scale development and reporting: a guide for researchers", Communication Methods and Measures, Vol. 12 No. 1, pp. 25-44.

Cassell, C., Nadin, S., Gray, M. and Clegg, C. (2002), "Exploring human resource management practices in small and medium-sized enterprises", Personnel Review, Vol. 31 No. 6, pp. 671-692.

Chen, C.J. and Huang, J.W. (2009), "Strategic human resource practices and innovation performance: the mediating role of knowledge management capacity", Journal of Business Research, Vol. 62 No. 1, pp. 104-114.

Crossan, M.M. and Apaydin, M. (2010), "A multi-dimensional framework of organizational innovation: a systematic review of the literature", Journal of Management Studies, Vol. 47 No. 6, pp. 1154-1191.

Damanpour, F. (1992), "Organizational size and innovation", Organization Studies, Vol. 13 No. 3, pp. 375-402.

Damanpour, F., Walker, R. and Avellaneda, C. (2009), "Combinative effects of innovation types and organizational performance: a longitudinal study of service organizations", Journal of Management Studies, Vol. 46 No. 4, pp. 650-650.

Damanpour, F., Szabat, K.A. and Evan, W.M. (1989), “The relationship between types of innovation and organizational performance", Journal of Management Studies, Vol. 26 No. 6, pp. 587-602.

Doherty, N. (1998), "The role of outplacement in redundancy management", Personnel Review, Vol. 27 No. 4, pp. 343-353.

Evangelista, R. and Vezzani, A. (2011), “The impact of technological and organizational innovations on employment in European firms", Industrial and Corporate Change, Vol. 21 No. 4, pp. 871-899.

Feldman, M.S. (2000), "Organizational routines as a source of continuous change", Organization Science, Vol. 11 No. 6, pp. 611-629.
Innovative human

resource management

299 
IJIS

12,3

Frey, C.B. and Osborne, M.A. (2013), "The future of employment", How Susceptible Are Jobs to Computerisation?, Oxford Martin Publication, Oxford.

Fritsch, U. and Görg, H. (2015), "Outsourcing, importing and innovation: evidence from firmlevel data for emerging economies”, Review of International Economics, Vol. 23 No. 4, pp. 687-714.

Fu, N., Flood, P.C., Bosak, J., Morris, T. and O'Regan, P. (2015), "How do high-performance work systems influence organizational innovation in professional service firms?", Employee Relations, Vol. 37 No. 2, pp. 209-231.

Goel, R.K. and Nelson, M.A. (2018), "Determinants of process innovation introductions: evidence from 115 developing countries", Managerial and Decision Economics, Vol. 39 No. 5, pp. 515-525.

Gerxhani, K. and Koster, F. (2015), "Making the right move: investigating employers' recruitment strategies", Personnel Review, Vol. 44 No. 5, pp. 781-800.

Hinkin, T.R. (1998), "A brief tutorial on the development of measures for use in survey questionnaires", Organizational Research Methods, Vol. 1 No. 1, pp. 104-121.

Hong, S., Oxley, L. and McCann, P. (2012), “A survey of the innovation surveys”, Journal of Economic Surveys, Vol. 26 No. 3, pp. 420-444.

Hult, G., Hurley, R. and Knight, G. (2004), "Innovativeness: its antecedents and impact on business performance", Industrial Marketing Management, Vol. 33 No. 5, pp. 429-438.

Huselid, M.A. (1995), "The impact of human resource management practices on turnover, productivity, and corporate financial performance”, Academy of Management Journal, Vol. 38 No. 3, pp. 635-672.

Jimenez-Jimenez, D. and Sanz-Valle, R. (2008), “Could HRM support organizational innovation?”, The International Journal of Human Resource Management, Vol. 19 No. 7, pp. 1208-1221.

Johne, A. (1999), "Successful market innovation", European Journal of Innovation Management, Vol. 2 No. 1, pp. 6-11.

Kaufman, B.E. and Miller, B.I. (2011), "The firm's choice of HRM practices: economics meets strategic human resource management", ILR Review, Vol. 64 No. 3, pp. 526-557.

Koster, F. (2011), "Able, willing and knowing. The effects of HR practices on commitment and effort in 26 European countries", The International Journal of Human Resource Management, Vol. 22 No. 14, pp. 2835-2851.

Koster, F. (2019), "Innovative HRM. A review of the literature”, Journal of Technology Management and Innovation, Forthcoming, Vol. 14 No. 2.

Koster, F., Korte, M., Van de Goorbergh, P. and Bloem, D. (2017), "Innovative HRM survey. Descriptive results", ICOON Paper 10. ICOON, Tilburg.

Koster, F. and Lambooij, M.S. (2018), "Managing innovations. A study of the implementation of electronic medical records in dutch hospitals", International Journal of Innovation and Technology Management, Vol. 15 No. 1, pp. 1850006.

Koster, F. and Wittek, R.P.M. (2016), "Competition and constraint. Economic globalization and human resource practices in 23 European countries", Employee Relations, Vol. 38 No. 2, pp. 286-303.

Laursen, K. and Foss, N.J. (2003), "New human resource management practices. Complementarities and the impact on innovation performance", Cambridge Journal of Economics, Vol. 27 No. 2, pp. 243-263.

Lepak, D.P. and Snell, S.A. (1999), "The human resource architecture: toward a theory of human capital allocation and development", The Academy of Management Review, Vol. 24 No. 1, pp. 31-48.

Maine, E., Lubik, S. and Garnsey, E. (2012), "Process-based vs product-based innovation: Value creation nanotech ventures", Technovation, Vol. 32 Nos 3/4, pp. 179-179.

March, J.G. (1991), "Exploration and exploitation in organizational learning", Organization Science, Vol. 2 No. 1, pp. 71-87.

Mateut, S. (2018), "Subsidies, financial constraints and firm innovative activities in emerging economies", Small Business Economics, Vol. 50 No. 1, pp. 131-162. 
Morris, D.M. (2018), “Innovation and productivity among heterogeneous firms”, Research Policy, Vol. 47 No. 10, pp. 1918-1932.

Murphy, G.D. and Southey, G. (2003), "High-performance work practices: perceived determinants of adoption and the role of the HR practitioner", Personnel Review, Vol. 32 No. 1, pp. 73-92.

Ng, I. and Dastmalchian, A. (2011), "Perceived training benefits and training bundles: a Canadian study", The International Journal of Human Resource Management, Vol. 22 No. 4, pp. 829-842.

Nguyen, H. and Jaramillo, P.A. (2014), Institutions and Firms' Return to Innovation: evidence from the World Bank Enterprise Survey, The World Bank, Washington, DC.

Oladapo, V. and Onyeaso, G. (2013), "An empirical investigation of Sub dimensions of highperformance work systems that predict organizational innovation”, International Journal of Management and Marketing Research, Vol. 6 No. 1, pp. 67-79.

Pouwels, I. and Koster, F. (2017), "Inter-organizational cooperation and organizational innovativeness. A comparative study", International Journal of Innovation Science, Vol. 9 No. 2, pp. 184-204.

Ramadani, V., Abazi-Alili, H., Dana, L.P., Rexhepi, G. and Ibraimi, S. (2017), "The impact of knowledge spillovers and innovation on firm-performance: findings from the Balkans countries", International Entrepreneurship and Management Journal, Vol. 13 No. 1, pp. 299-325.

Rasheed, M.A., Shahzad, K., Conroy, C., Nadeem, S. and Siddique, M.U. (2017), "Exploring the role of employee voice between high-performance work system and organizational innovation in small and medium enterprises", Journal of Small Business and Enterprise Development, Vol. 24 No. 4, pp. 670-688.

Revelle, W. (2018), Psych: Procedures for Personality and Psychological Research, Northwestern University, Evanston, available at: https://CRAN.R-project.org/package=psychVersion=1.8.12

Rosseel, Y. (2012), "Lavaan: an R package for structural equation modeling", Journal of Statistical Software, Vol. 48 No. 2, pp. 1-36, available at: www.jstatsoft.org/v48/i02/

Sels, L., De Winne, S., Delmotte, J., Maes, J., Faems, D. and Forrier, A. (2006), "Linking HRM and small business performance: an examination of the impact of HRM intensity on the productivity and financial performance of small businesses", Small Business Economics, Vol. 26 No. 1, pp. 83-101.

Shaw, J.D., Dineen, B.R., Fang, R. and Vellella, R.F. (2009), "Employee-organization exchange relationships, HRM practices, and quit rates of good and poor performers", Academy of Management Journal, Vol. 52 No. 5, pp. 1016-1033.

Shipton, H., West, M., Dawson, J., Birdi, K. and Patterson, M. (2006), "HRM as a predictor of innovation", Human Resource Management Journal, Vol. 16 No. 1, pp. 3-27.

Shipton, H., Sparrow, P., Budhwar, P. and Brown, A. (2017), "HRM and innovation: looking across levels", Human Resource Management Journal, Vol. 27 No. 2, pp. 246-263.

Som, A. (2007), "What drives adoption of innovative SHRM practices in Indian organizations?", The International Journal of Human Resource Management, Vol. 18 No. 5, pp. 808-828.

Som, A. (2012), "Organizational response through innovative HRM and re-design: a comparative study from France and India”, The International Journal of Human Resource Management, Vol. 23 No. 5, pp. 952-976.

Subramony, M. (2006), "Why organizations adopt some human resource management practices and reject others: an exploration of rationales", Human Resource Management, Vol. 45 No. 2, pp. 195-210.

Tidd, J. and Bessant, J.R. (2018), Managing Innovation: integrating Technological, Market and Organizational Change, John Wiley and Sons, Hoboken.

Tzafrir, S.S. (2005), "The relationship between trust, HRM practices and firm performance", The International Journal of Human Resource Management, Vol. 16 No. 9, pp. 1600-1622.
Innovative human

resource management

301 
IJIS

12,3

Walsworth, S. and Verma, A. (2007), "Globalization, human resource practices and innovation: recent evidence from the Canadian workplace and employee survey", Industrial Relations, Vol. 46 No. 2 , pp. 222-240.

Wellalage, N.H. and Fernandez, V. (2019), "Innovation and SME finance: evidence from developing countries", International Review of Financial Analysis, Vol. 66.

Wolfe, R., Wright, P.M. and Smart, D.L. (2006), "Radical HRM innovation and competitive advantage: the moneyball story", Human Resource Management, Vol. 45 No. 1, pp. 111-145.

Wu, N., Bacon, N. and Hoque, K. (2014), "The adoption of high-performance work practices in small businesses: the influence of markets, business characteristics and HR expertise", The International Journal of Human Resource Management, Vol. 25 No. 8, pp. 1149-1169.

Zheng, C., O'Neill, G. and Morrison, M. (2009), "Enhancing Chinese SME performance through innovative HR practices", Personnel Review, Vol. 38 No. 2, pp. 175-194.

\section{Further reading}

Foster, C. and Harris, L. (2005), "Easy to say, difficult to do: diversity management in retail", Human Resource Management Journal, Vol. 15 No. 3, pp. 4-17.

\section{Corresponding author}

Ferry Koster can be contacted at: koster@essb.eur.nl

For instructions on how to order reprints of this article, please visit our website: www.emeraldgrouppublishing.com/licensing/reprints.htm

Or contact us for further details: permissions@emeraldinsight.com 